\title{
Hubungan Eosinofil dan Neutrofil Darah Tepi terhadap Derajat Keparahan Asma pada Pasien Asma di Bagian Rawat Inap Paru RSUP Dr. M. Djamil Padang Periode 2010 - 2013
}

\author{
Dwiyana Roselin ${ }^{1}$, Eryati Darwin ${ }^{2}$, Irvan Medison ${ }^{3}$
}

\begin{abstract}
Abstrak
Asma adalah penyakit inflamasi kronik yang ditandai dengan adanya infiltrasi sel-sel radang, termasuk eosinofil dan neutrofil. Kedua sel ini dapat melepaskan protein-protein yang mempunyai efek toksik langsung terhadap epitel saluran nafas sehingga terjadi kerusakan langsung pada epitel tersebut yang dapat memperburuk derajat serangan asma. Tujuan penelitian ini adalah menentukan hubungan eosinofil dan neutrofil terhadap derajat keparahan asma. Telah dilakukan penelitian cross sectional analytic untuk mengetahui hubungan eosinofil dan neutrofil darah tepi terhadap derajat keparahan asma di Bagian Rawat Inap Paru RSUP. Dr. M. Djamil Padang periode 2010 - 2013. Populasi adalah pasien yang didiagnosa menderita asma. Sampel adalah populasi yang memenuhi kriteria inklusi. Analisis dari penelitian ini menggunakan uji Chi-Square dengan derajat kepercayaan 95\%. Dari 31 pasien dengan asma, insiden terbanyak asma berada pada kelompok usia 41 - 60 tahun (48.4\%), jumlah perempuan lebih banyak (71\%) dibanding dengan laki-laki (19\%) dan paling banyak datang denga asma persisten sedang (64.5\%). Eosinifiia terdapat pada 1 kasus (3.3\%). Analisis statistik menunjukan bahwa tidak terdapat hubungan yang bermakna eosinofil darah tepi terhadap derajat keparahan asma ( $p>0.05)$. Neutrofilia terdapat pada 27 kasus (87\%). Analisis statistik menunjukan bahwa tidak dapat mencari hubungan neutrofil darah tepi terhadap derajat keparahan asma.
\end{abstract}

Kata kunci: eosinofil, neutrofil, keparahan asma

\begin{abstract}
Asthma is a chronic inflamation disease indicated by inflamed cell infiltration including eosinophil and neutrophil. These cell also relase the proteins with direct toxic effect on respiratory tract epithelium, so that an immediate change happen on epithelium, even deteriorating the degree of asthma. The objective of this study was to determine the relationship eosinophil and neutrophil on the degree of asthma. A cross sectional analytic study had been carried out to know whether the relationship between eosinophil and neutrophil in peripheral blood and the degree of asthma in the part department care unit of the lungs in RSUP. Dr. M. Djamil Padang period $2010-2013$. The population is patient in lung health department wich diagnose as asthma and come with exacerbation. The samples were the population that meet the inclusion criteria. The analysis used for this experiment was chi-square test with credibility level of $95 \%$. From 31 patients with asthma, most patient are $41-60$ years old. Women (71\%) had a higher rate than man (19\%) and most of them come with moderate persistent asthma (64.5\%). Eosinophilia patiens are 1 case (3.3\%) and the statistic analysis was no sinificant relation between eosinophil in peripheral blood and the degree of asthma $(p>0.05)$. Neutrophilia patiens were 27 cases $(87 \%)$ and from the statistic analysis, there was no relation between neutrophil in peripheral blood and the degree of asthma.
\end{abstract}

Keywords: eosinophil, neutrophil, degree of asthma

Affiliasi penulis: 1. Prodi Profesi Dokter FK Unand (Fakultas Kedokteran Universitas Andalas Padang), 2. Bagian Histologi FK Unand, 3. Bagian Paru FK Unand/RSUP. Dr. M.Djamil
Korespondensi: Dwiyana Roselin, Email

dwiyana.roselin@yahoo.ci.id, Telp: 085658166193 


\section{PENDAHULUAN}

Asma adalah penyakit kronik inflamasi saluran nafas dimana pada proses ini terdapat peran sel-sel inflamasi seperti eosinofil, neutrofil, limfosit dan lainlain. Proses inflamasi yang terjadi berasosiasi dengan saluran nafas yang hiperresponsif sehingga hal ini bisa menyebabkan episode serangan asma seperti mengi, sesak nafas, dada terasa sempit, dan batukbatuk terutama di malam hari. $^{1}$ Asma merupakan penyakit kronik yang banyak diderita oleh anak maupun dewasa baik di negara maju ataupun di negara berkembang. Sekitar 100 juta sampai 150 juta orang di dunia menderita asma dan diprediksi jumlah ini akan bertambah tiap tahunnya, sedangkan kematian akibat asma di dunia telah mencapai 180.000 juta orang tiap tahunnya di dunia. Penderita asma di Jerman mencapai 4 juta orang, di Eropa Barat jumlah asma menjadi dua kali lipat tiap tahunnya, di Amerika Serikat prevalensi asma sudah meningkat $60 \%$ sejak tahun 1980-an dan kematian telah mencapai 5000 orang tiap tahunnya, di Jepang penderita asma telah mencapai tiga juta orang dengan penderita asma derajat berat $7 \%$ dan asma derajat sedang $30 \%$, sedangkan di Australia satu dari enam anak di bawah 16 tahun mengidap asma. Asma tidak hanya terdapat pada negara maju, di negara berkembang prevalensi asma juga tinggi, di India terdapat 15 juta sampai 20 juta orang mengidap asma, di Brazil, Costa Rica, Panama, Peru dan Uruguai prevalensi asma pada anak sudah mencapai $20-30 \%{ }^{2}$ Prevalensi penyakit asma di Indonesia sebesar 3,32\%. Prevalensi tertinggi penyakit asma adalah provinsi Gorontalo $(7,23 \%)$ dan terendah adalah NAD (Nangro Aceh Darusalam) sebesar $0,09 \%$ dan di Sumatra Barat 3,58\%. ${ }^{3}$

Survei asma nasional di Indonesia belum ada, tetapi dari penelitian yang ada menyimpulkan bahwa prevalensi asma di daerah rural (4.3\%) lebih rendah dari pada daerah urban $(6.5 \%)$ dan yang tertinggi adalah kota besar seperti di Jakarta $(16,4 \%)$.

Asma dapat dinilai berdasarkan derajat keparahan, derajat ini terbagi atas intermiten, persisten ringan, persisten sedang, dan persisten berat. Global Initiative for Asthma (GINA) membagi derajat serangan asma berdasarkan gejala, tanda klinis, uji fungsi paru dan pemeriksaan laboratorium. Di Indonesia penilaian derajat keparahan asma hanya berdasarkan gejala klinis saja karena alat untuk uji fungsi paru (spirometer) belum memasyarakat. ${ }^{1}$

Parameter klinis untuk derajat keparahan asma menurut GINA adalah: frekuensi terjadinya serangan, frekuensi terjadinya serangan pada malam hari dan hasil spirometri. Konsep terbaru patogenesis asma adalah proses inflamasi kronik pada saluran pernapasan sehingga saluran pernapasan menjadi sempit dan hiperesponsif. ${ }^{1}$

Asma dalam derajat apapun tetap terjadi inflamasi kronik saluran nafas, inflamasi ini sudah terdapat pada asma dini dan asma ringan dan sudah terjadi sebelum gangguan fungsi paru. Gambaran khas inflamasi ditandai dengan peningkatan jumlah eosinofil yang teraktivasi, sel mast, makrofag, dan limfosit $\mathrm{T}$ dalam lumen mukosa saluran pernapasan. ${ }^{1}$ Degranulasi sel mast dan limfosit $T$ subtipe Th2 akan menggerakkan dan mengaktifkan sel-sel inflamasi seperti eosinofil, basofil, netrofil dan makrofag. Eosinofil akan memproduksi toksin inflamatori yang disimpan dalam granul-granul seperti Major Basic Protein dan matrix yang terdiri dari Eosinophil Cationic Protein, peroksidase eosinofil, dan Eosinophil Derived Neurotoxin yang mengandung efek sitotoksin pada epitelium respiratori sehingga terjadi kerusakan epitel saluran napas. ${ }^{4}$ Walaupun konsep inflamasi eosinofil sudah lama dipertimbangakan sebagai penyebab asma, sekarang sudah munsul teori baru yang mengatakan pada asma derajat berat peranan eosinofil akan berkurang, netrofil akan lebih berperan pada kerusakan saluran pernapasan pada asma derajat berat.

Penelitian ini penting agar dapat diketahui bagimana hubungan eosinofil dan neutrofil terhadap derajat keparahan asma dan mengapa hal ini terjadi.

\section{METODE}

Penelitian ini merupakan suatu studi retrospektif cross-sectional analytic untuk melihat hubungan eosinofil dan neutrofil darah tepi terhadap derajat keparahan asma pada pasien yang didiagnosa asma di Bagian Rawat Inap Paru RSUP Dr. M. Djamil Padang. Populasi penelitian ini adalah semua pasien 
yang didiagnosa asma di Bagian Rawat Inap Paru pada periode 1 Januari 2010 - 31 Desember 2013, sampel peneltian adalah semua pasien yang didiagnosa asma pada periode tersebut. Kriteria inklusi pasien yang didiagnosa asma dan pasien yang memiliki data rekam medis yang lengkap, khususnya usia, jenis kelamin, klasifikasi asma berdasarkan derajat keparahan, pemeriksaan laboratorium hitung jenis leukosit darah tepi, dan jumlah leukosit total. Kriteria eksklusi adalah pasien yang memiliki data rekam medis yang tidak lengkap dan penyakit yang menyertai asma yang akan mempengaruhi hitungan leukosit pasien. Variabel bebas peneltian ini adalah jumlah eosinofil dan neutrofil darah tepi, variabel tergantung adalah derajat keparahan asma, dan variabel confounding adalah usia dan jenis kelamin. Penelitian ini menggunakan data sekunder yang diperoleh dari rekam medis pasien asma dan data pasien asma di Bagian Paru di RSUP Dr. M. Djamil Padang yang mengalami rawat inap di Instalasi Rawat Inap Paru RSUP Dr. M. Djamil Padang. Sebelum pengumpulan data didahului dengan meminta izin ke Bagian Rekam Medis dan Bagian Paru RSUP Dr. M. Djamil Padang untuk mendapat data pasien asma. Pengolahan data dilakukan dengan memeriksa kelengkapan dan kejelasan data, pemberian kode pada setiap variabel, memasukkan data ke dalam program komputer, dan pemeriksaan kembali data yang sudah dimasukkan. Data kemudian diolah menggunakan analisis univariat dan bivariat. Analisis bivariat dilakukan dengan uji chi square.

\section{HASIL}

Setelah melakukan pencatatan di bagian rekam medik rawat inap paru dan bagian paru RS. Dr. M. Djamil Padang, diperoleh informasi bahwa terdapat 100 pasien asma yang dirawat di bagian rawat inap paru RS. Dr. M. Djamil Padang periode Januari 2010 Desember 2013. Data dari Januari 2011 - Desember 2011 tidak ditemukan dan dari keseluruhan kasus tersebut yang memenuhi kriteria sampel adalah sebanyak 31 sampel karena 37 kasus tidak ditemukan catatan hasil pemeriksaan hitung jenis leukosit dan 32 kasus yang tidak ditemukan lagi catatan status karena hilang.
Tabel 1. Tabel karakteristik pasien asma di bagian rawat inap paru RSUP Dr. M. Djamil Padang periode 1 Januari 2010 - 31 Desember 2013

\begin{tabular}{lc}
\hline Karakteristik & $\mathbf{n}$ \\
\hline Rata-rata Usia & 96 tahun $(18-80$ tahun $)$ \\
Laki-laki & 22 orang \\
Perempuan & $14.381 / \mathrm{mm}^{3}(7.600-$ \\
Jumlah Leukosit & $\left.28.300 / \mathrm{mm}^{3}\right)$ \\
& $71 / \mathrm{mm}^{3}\left(0-505 / \mathrm{mm}^{3}\right)$ \\
Jumlah Eosinofil & $12343 / \mathrm{mm}^{3}(5.717-$ \\
Jumlah Neutrofil & $26.885 / \mathrm{mm}^{3)}$ \\
Keparahan Asma & 4 orang \\
Asma Intermiten & 4 orang \\
Asma Persisten & \\
ringan & 20 orang \\
Asma Persisten & \\
sedang & 3 orang \\
Asma Persisten & \\
berat &
\end{tabular}

Tabel diatas memperlihatkan bahwa frekuensi tertinggi pasien asma yang dirawat di bagian inap paru RS. Dr. M. Djamil Padang adalah kelompok usia 41 60 tahun (48.4\%). Diketahui bahwa dari 31 pasien asma yang dirawat di bagian rawat inap paru RS. Dr. M. Djamil Padang, perempuan lebih banyak yaitu 22 pasien $(71 \%)$ dan didapatkan penderita asma terbanyak datang dengan derajat keparahan asma persisten sedang yaitu sebanyak 20 kasus (64.5\%). Penderita asma dengan eosinofilia $\left(>400 / \mathrm{mm}^{3}\right)$ adalah hanya 1 kasus (3.2\%) dan penderita asma dengan neutrofilia $\left(>5000 / \mathrm{mm}^{3}\right.$ ) adalah 27 kasus.

Tabel 2. Hubungan eosinofil darah tepi terhadap derajat keparahan pada pasien asma di bagian rawat inap anak RSUP Dr. M. Djamil Padang periode 1 Januari 2010 - 31 Desember 2013.

\begin{tabular}{|c|c|c|c|c|c|}
\hline \multirow[b]{2}{*}{$\begin{array}{c}\text { Eosinofil- } \\
\text { Darah } \\
\text { Tepi }\end{array}$} & \multicolumn{4}{|c|}{ Derajat Keparahan Asma } & \multirow[b]{2}{*}{$p$} \\
\hline & $\begin{array}{l}\text { Inter- } \\
\text { miten } \\
\mathrm{n}(\%)\end{array}$ & $\begin{array}{c}\text { Persisten } \\
\text { Ringan } \\
\mathrm{n}(\%)\end{array}$ & $\begin{array}{c}\text { Persisten } \\
\text { Sedang } \\
\mathrm{n}(\%)\end{array}$ & $\begin{array}{c}\text { Persisten } \\
\text { Berat } \\
\text { n(\%) }\end{array}$ & \\
\hline$<40$ & $\begin{array}{c}2 \\
(9.1)\end{array}$ & $\begin{array}{c}3 \\
(13.6)\end{array}$ & $\begin{array}{c}15 \\
(68.2)\end{array}$ & $\begin{array}{c}2 \\
(9.1)\end{array}$ & \\
\hline $\begin{array}{c}\geq 40 \\
/ \mathrm{mm}^{3}\end{array}$ & $\begin{array}{c}2 \\
(22.3)\end{array}$ & $\begin{array}{c}1 \\
(11.2)\end{array}$ & $\begin{array}{c}5 \\
(55.5)\end{array}$ & $\begin{array}{c}1 \\
(11.2)\end{array}$ & 0.784 \\
\hline
\end{tabular}


Pembagian kelompok eosinofil darah tepi pada awalnya adalah: $<40 / \mathrm{mm}^{3}, 40-400 / \mathrm{mm}^{3}$, dan $>400 / \mathrm{mm}^{3}$. Namun karena terdapat nilai 0 pada salah satu sel, maka kelompok eosinofil darah tepi 40$400 / \mathrm{mm} 3$ dan $400 / \mathrm{mm}^{3}$ dimodifikasi menjadi " $\geq 40$ $/ \mathrm{mm}^{3 \text { " }}$ dan kelompok "< $40 / \mathrm{mm}^{3}$ " tetap digunakan.

Pada Tabel 2 terlihat bahwa presentase penderita asma persisten berat pada kadar eosinofil < $40 / \mathrm{mm}^{3}(11.2 \%)$ lebih banyak daripada penderita asma pada kadar eosinofil $\geq 40 / \mathrm{mm}^{3}(9.1 \%)$. Secara statistik menunjukan tidak terdapat hubungan bermakna $(p>0.05)$ antara eosinofil darah tepi terhadap derajat keparahan asma karena didapatkan jumlah $p=0.784$.

Tabel 3. Gambaran netrofil darah tepi terhadap derajat keparahan asma pada pasien rawat inap paru RSUP Dr. M. Djamil Padang periode 1 Januari 2010 - 31 Desember 2013.

\begin{tabular}{|c|c|c|c|}
\hline \multirow[b]{2}{*}{$\begin{array}{l}\text { Neutrofil } \\
\text { Darah Tepi }\end{array}$} & \multicolumn{2}{|c|}{ Derajat Keparahan Asma } & \multirow[b]{2}{*}{$\begin{array}{l}\text { Jumlah } \\
\text { n(\%) }\end{array}$} \\
\hline & $\begin{array}{l}\text { Intermiten dan } \\
\text { Persisten } \\
\text { Ringan } \\
\mathrm{n}(\%)\end{array}$ & $\begin{array}{c}\text { Persisten } \\
\text { Sedang dan } \\
\text { Persisten } \\
\text { Berat } \\
\text { n(\%) }\end{array}$ & \\
\hline$<7000 / \mathrm{mm}^{3}$ & $1(50)$ & $1(50)$ & $2(100)$ \\
\hline$\geq 7000 / \mathrm{mm}^{3}$ & $1(14 \%)$ & $6(86 \%)$ & $7(100)$ \\
\hline
\end{tabular}

Pembagian kelompok neutrofil darah tepi pada awalnya adalah: $<2000 / \mathrm{mm}^{3}, 2000-7000 / \mathrm{mm}^{3}$, dan $>70000 / \mathrm{mm}^{3}$. Namun karena terdapat nilai 0 pada salah satu sel, maka kelompok eosinofil darah tepi $<2000 / \mathrm{mm} 3$ dan 2000-7000/mm ${ }^{3}$ dimodifikasi menjadi "<7000 $/ \mathrm{mm}^{3 "}$ dan kelompok " $\geq 7000 / \mathrm{mm}^{3}$ " tetap digunakan. Pembagian kelompok keparahan asma pada awalnya adalah: intermiten, persisten ringan, persisten sedang, dan persisten berat. Namun karena terdapat nilai 0 pada salah satu sel, maka kelompok keparahan asma intermiten dan persisten ringan digabungkan dan kelompok keparahan asma persisten sedang dan persisten berat digabungkan.

Tabel 3 memperlihatkan hubungan neurtofil dan keparahan asma tidak dapat dihitung karena terdapat 21 pasien dengan comorbid adalah bronkitis. bronkitis. Hal ini yang akan menyebabkan perubahan pada jumlah neutrofil sehingga tidak bisa mencari hubungan neutrofil dengan keparahan asma.

\section{PEMBAHASAN}

Berdasarkan hasil peneltian yang telah dilakukan maka didapatkan dari 100 pasien asma yang dirawat di bagian rawat inap paru RS . Dr. M. Djamil Padang periode Januari 2010 - Desember 2013, kelompok terbanyak pada usia 41 - 60 tahun (48.4\%). Penelitian yang dilakukan oleh Akinbami et al mendapatkan hasil yang berbeda yaitu asma pada pasien dewasa kelompok terbanyaknya adalah pada usia lebih dari 65 tahun. Perbedaan hasil dapat disebabkan karena sampel penelitian yang berbeda. Pada peneltian ini data diperoleh dari pasien yang rawat inap di bangsal paru sedangkan Akinbami et al memperoleh data dari pasien asma di rumah sakit yang diambil secara random. ${ }^{5}$

Pada penelitian ini didapatkan jumlah perempuan dengan asma sebanyak 22 orang $(71 \%)$ dan jumlah laki-laki dengan asma sebanyak 9 orang (29\%). Hal ini menunjukan bahwa pada pasien perempuan dewasa yang banyak mengidap asma berbeda dengan pasien anak dimana laki-laki yang lebih banyak mengidap asma. Sama dengan penelitian yang dilakukan oleh Kynyk et al dimana prevalensi pada pasien asma yang berumur $<15$ tahun perbandingan laki-laki dan perempuan yaitu $11.9 \%$ dan $7.7 \%$, pada pasien asma yang berumur $15-34$ tahun perbandingan laki-laki dan perempuan adalah $6.3 \%$ dan $9.6 \%$, dan pada pasien asma yang berumur $>35$ tahun perbandingan laki-laki dan perempuan yaitu $5.6 \%$ dan $10.1 \%$. Terjadinya perbedaan ini masih belum jelas penyebabnya tapi pada dewasa ada hubungan dengan bronkial yang lebih hiperresponsif pada perempuan dewasa, tingkat ansietas yang lebih tinggi pada perempuan, otot respirasi yang lebih lemah pada perempuan dan adanya perubahan hormon sex pada perempuan bisa mempengaruhi perkembangan asma dan keparahannya hal ini juga dibukitkan dengan penurunan prevalensi asma pada perempuan yang sudah menopause. ${ }^{6}$ 
Tabel 3 memperlihatkan 20 pasien (64.5\%) dengan asma persisten, sedangkan 4 pasien (12.9\%) dengan asma intermiten, 4 pasien (12.9\%) dengan asma persisten ringan, dan 3 pasien (9.6\%) dengan asma persisten berat. Hasil ini sama dengan penelitian yang dilakukan oleh Zhang et al. ${ }^{7}$

Kadar eosinofilia lebih dari 400/ $\mathrm{mm}^{3}$ ditemukan sebanyak 1 dari 31 pasien (3.2\%). Dari hasil ini didapat bahwa tidak mutlak terdapat peninngian kadar eosinofil pada pemeriksaan darah tepi penderita asma, dikarenakan 8 kasus (25.8\%) jumlah eosinofil masih dalam batas normal dan 22 kasus (71\%) jumlah eosinofil dibawah normal.

Eosinofilia tidak mutlak muncul memang sangat mungkin terjadi, hal ini bisa dikarenakan tidak semua pasien asma merupakan penderita asma bronkial alergik atau penyakit atopik, yaitu berdasarkan reaksi alergi atau reaksi hipersensitivitas tipe I. Sehingga tidak ditemukan tanda-tanda reaksi hipersensitivitas terhadap alergen, termasuk peningkatan eosinofil pada darah tepi. ${ }^{8}$

Kelemahan yang mungkin terjadi pada peneltian ini karena hanya menggunakan data pemeriksaan hitung jenis leukosit dati catatan rekam medik pasien, dikarenakan adanya keterbatasan dana dan waktu. Diharapkan penelitian ini dapat dilanjutkan dimasa yang akan datang dengan menggunakan metode hitung jenis eosinofil dan neutrofil total dan dikerjakan secara prospektif.

Ketidakakuratan ini dapat juga disebabkan karena data rekam medik yang diperoleh tidak mencantumkan pengobatan apa yang telah diterima pasien sebelum dirawat di rumah sakit. Terapi dengan menggunakan kortikosteroid seperti prednison peroral atau hidrokortison intravena maupun intramuskular dapat menekan jumlah leukosit. ${ }^{9}$

Hasil analisis statistik didapat bahwa tidak terdapat hubungan antara jumlah eosiofil penderita asma dengan derajat keparahan asma intermiten, peristen ringan, persisten sedang, dan persisten berat. Hal ini tidak sesuai dengan pendapat bahwa eosinofilia berkorelasi dengan beratnya dan aktifnya asma. $^{10}$

Tidak adanya pengaruh eosinofil terhadap berat ringannya asma kemungkinan karena asma selain disebabkan oleh alergen, dapat juga oleh perangsangan lain seperti stres fisik dan psikis, perubahan cuaca atau infeksi yang tidak berhubungan dengan paparan terhadap alergen, sehingga tidak dapat meningkatkan jumlah eosinofil melalui lgE. ${ }^{11}$

Neutrofilia $\left(>7000 / \mathrm{mm}^{3}\right)$ ditemukan sebanyak 27 dari 31 kasus (87.1\%). Hal ini dapat mendukung pendapat Monteseirin ${ }^{12}$ yang menyatakan pasien yang mengidap asma yang simptomatis memiliki neutrofil darah tepi yang lebih tinggi. Tetapi hubungan neutrofil darah tepi dengan derajat keparahan asma tidak dapat dicari karena banyaknya pasien dengan infeksi sehingga mennganngu perhitungan neutrofil. Hal ini tidak bisa membuktikan teori yang menyatakan bahwa neutrofilia berkorelasi dengan tingkat kontrol asma. ${ }^{12}$ Kelemahan penelititan ini karena banyaknya pasien dengan diagnosis sekunder infeksi, sehingga tidak bisa mencari hubungan neutrofil terhadap keparahan asma. Oleh karena itu diharapkan pada masa yang akan datang diharapkan akan ada penelitian yg melihat hubungan neutrofil terhadap derajat keparahan asma dimana diagnosa penyakitnya memang hanya asma tanpa ada diagnosa sekunder infeksi atau penyakit lainnya.

\section{SIMPULAN}

Tidak terdapat hubungan eosinophil terhadap derajat keparahan asma.

Hubungan neutrofil terhadap derajat keparahan asma tidak dapat dicari karena banyaknya sampel yang infeksi, sehingga mempengaruhi jumlah neutrofil.

\section{DAFTAR PUSTAKA}

1. GINA (Global Initiative for Asthma). Global strategy for asthma management and prevention. NHLBI/WHO: Workshop report. National Instituse; 2011.

2. WHO. Bronkial asthma. 2013 (diunduh 2014). Tersedia dari: URL: HYPERLINK http://www.who. int/mediacentre/factsheets/fs206/en/

3. Oemiati R, Sihombing M, Qomariah. Faktor-faktor yang berhubungan dengan penyakit asma di Indonesia. Media Litbang Kesehatan. 2010;20(1):41-9.

4. Dedi A. Eosinofil dan patogenesa asma. Majalah Kedokteran Nusantara. 2008;(4):1-14. 
5. Akinbami L, Moorman J, Bailey C, Zahran H, King M. Trends in asthma prevalence, health care use, and mortality in the United States. NCHS data brief; 2000.

6. Kynyk J, Mastronade J, McCallister J. Asthma, the sex difference. Curr Opin Pulm Med. 2011; 17(1): 6-11.

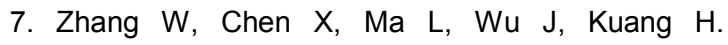
Epidemiology of bronchial asthma and asthma control assessment in Henan Province, China. Translational Respiratory Medicine. 2014(2):5.

8. Williams RS. Asma bronkial: alergi dan lain-lain. Dalam: Sylvia AP et al, editor (penyunting). Patophysiology clinical concept of disease process.
Edisi ke-4. Alih bahasa: Anugerah P. Jakarta: EGC; 1994. hlm 149-55.

9. Staf Pengajar IImu Kesehatan FKUI. Asma. buku kuliah ilmu kesehatan anak jilid III. Jakarta: Infomedika,1985:1203.

10. Sundaru H. Asma bronkial. Dalam: Buku Ajar Penyakit Dalam II. Edisi ke-3. Jakarta: Balai Penerbit FKUI; 2001:21-31.

11. Hood A, Sandika W. Sistem pernapasan. Buku Ajar Patologi 11. Edisid ke-4. Jakarta: EGC;1995:144-5.

12. Monteseirin J. Neutrophils and asthma. J investigation Allergol Clinnical Immunologi. 2009;19(5):340-54. 